\title{
Analisa Fungsi dan Pengaruh Bangunan Pengendali Banjir DAS Ampal Kota Balikpapan
}

\author{
Rossana Margaret Kadar Yanti ${ }^{1}$, Edijatno ${ }^{2}$, Umboro Lasminto ${ }^{3}$ \\ ${ }^{1}$ Teknik Sipil, Teknik Sipil dan Perencanaan, Institut Teknologi Kalimantan, Balikpapan. Email: \\ rossa.margareth@itk.ac.id \\ 2,3 Teknik Sipil, Teknik Sipil dan Perencanaan, Institut Teknologi Sepuluh Nopember, Surabaya.
}

\begin{abstract}
Ampal Catchment Area has $25.273 \mathrm{~km}^{2}$ area and $4.699 \mathrm{~km}$ main river length, which planned to have 13 flood control building. To 2017, this catchment area has only three flood control building. The watershed has only three built-in batters that are used to reduce the amount of flood discharge flowing on the Ampal river. Based on these conditions, it is necessary to analyze the magnitude of the difference of flood peak discharge on the existing condition (three bendali) compared with the condition of the plan (thirteen bendali). Therefore, the function and the influence of flood control building was analyzed in Ampal Catchment Area by counting the flood peak discharge in each condition. The analysis result show, obtained the amount of peak discharge flowing in Ampal river existing condition is equal to $170,40 \mathrm{~m}^{3} / \mathrm{s}$ while at the condition of plan is equal to $83,80 \mathrm{~m}^{3} / \mathrm{s}$. The results of analysis show, it is stated that the magnitude of the decrease of debit $(\Delta \mathrm{Q})$ after all the builds is $86.60 \mathrm{~m}^{3} / \mathrm{s}$.
\end{abstract}

Keywords: Ampal Catchment Area, Flood control building, Flood.

\begin{abstract}
Abstrak
DAS Ampal memiliki luas sebesar 2527ha dengan panjang sungai utama sepanjang 4,699 km direncanakan memiliki 13 bangunan pengendali banjir. Sampai dengan tahun 2017, DAS ini hanya memiliki tiga bendali terbangun yang digunakan untuk mengurangi besarnya debit banjir yang mengalir pada sungai Ampal. Berdasarkan kondisi tersebut, maka diperlukan analisa guna mengetahui besarnya perbedaan debit puncak banjir pada kondisi eksisting (tiga bendali) dibanding dengan kondisi rencana (tiga belas bendali). Oleh karena itu, dilakukan analisa fungsi dan pengaruh bangunan pendali banjir di DAS Ampal dengan cara menghitung debit puncak banjir pada masing-masing kondisi. Dari hasil analisa, diperoleh besarnya debit puncak yang mengalir pada sungai Ampal kondisi eksisting adalah sebesar 170,40 $\mathrm{m}^{3} /$ det sedangkan pada kondisi rencana adalah sebesar $83,80 \mathrm{~m}^{3} / \mathrm{det}$. Dari hasil analisa, dikatehui bahwa besarnya penurunan debit $(\Delta \mathrm{Q})$ setelah semua bendali terbangun adalah sebesar $86,60 \mathrm{~m}^{3} / \mathrm{det}$.
\end{abstract}

Keywords: DAS Ampal, Bangunan Pengendali Banjir, Banjir.

\section{Pendahuluan}

DAS Ampal atau DAS Klandasan Besar terletak di Kecamatan Balikpapan Barat, Kota Balikpapan. Sungai Ampal merupakan sungai utama yang terdapat pada DAS ini dan memiliki panjang 4,699 km yang bermuara di Selat Makassar. Luas daerah tangkapan DAS Ampal adalah sebesar 2527 ha dengan tutupan lahan yang terdiri dari pemukiman/perumahan, kawasan industri, dan kawasan sektoral (Bappeda Kota Balikpapan, 2006).

Sistem drainase DAS Ampal terdiri dari saluran primer, sekunder dan tersier. Sebagai sungai utama, Sungai Ampal berperan sebagai saluran primer yang bermuara di laut (selat Makassar). Sungai Ampal berperan mengalirkan debit banjir dari daerah hulu yang dilewatkan pada daerah perkotaan menuju 
badan air. Permasalahan drainase yang terjadi pada DAS Ampal saat ini adalah banjir yang disebabkan karena kapasitas saluran lebih kecil dibanding dengan debit banjir. Hal ini disebabkan oleh tingginya curah hujan, koefisien pengaliran yang meningkat, dan kapasitas sungai yang menurun akibat adanya sedimentasi (FTSP ITS, 2006).

Dengan adanya banjir yang ada pada DAS Ampal, Pemerintah Kota Balikpapan melakukan upaya pembangunan bangunan pengendali banjir di beberapa titik rawan banjir guna mengatasi permasalahan yang ada. DAS Ampal direncanakan dilengkapi dengan 13 bangunan pengendali banjir serta akan dilakukan perbaikan sungai sepanjang $12811 \mathrm{~m}$. Sampai dengan saat ini, pelaksanaan program pengendalian banjir yang telah dilaksanakan adalah pembangunan 3 bangunan pengendali banjir yaitu Bendali 11, Bendali 12 dan Bendali 13 (FTSP ITS, 2006).

Studi ini membahas peran serta fungsi 3 bangunan pengendali banjir yang telah terbangun pada DAS Ampal. Dalam studi ini, dilakukan analisa pengaruh bangunan pengendali banjir terhadap penurunan debit puncak banjir DAS Ampal. Tujuan dari studi ini adalah mengetahui besarnya penurunan debit banjir setelah bangunan pengendali banjir terbangun.

\section{Metodologi}

Sistematika dalam pelaksanaan penelitian terkait analisa fungsi dan pengaruh bangunan pengendali banjir di DAS Ampal adalah sebagai berikut:

\subsection{Identifikasi Masalah}

Identifikasi masalah merupakan tahapan dilakukan untuk mengetahui lebih lanjut terkait permasalahan yang terjadi khususnya di DAS Ampal. Tahap ini bertujuan untuk mengetahui langkah penelitian yang harus dilakukan guna mencapai tujuan yang telah ditentukan.

\subsection{Tahap Persiapan}

Tahap ini dilakukan untuk mengetahui gambaran kondisi dan lokasi DAS Ampal Kota Balikpapan secara umum. Tahap persiapan dilakukan dengan serangkaian kegiatan yaitu survei kondisi lapangan dan studi literatur yang bertujuan untuk menunjang pelaksanaan penelitian.

\subsection{Pengumpulan Data}

Pengumpulan data dilakukan untuk memperoleh informasi secara spesifik terkait kondisi dan permasalahan yang terjadi di DAS Ampal. Pengumpulan data DAS Ampal diperoleh dari berbagai sumber, yaitu :

1. Badan Perencanaan Pembangunan Daerah (BAPPEDA) Kota Balikpapan yang berupa data curah hujan maksimum tahunan, peta lokasi DAS Ampal, penampang melintang dan memanjang sungai Ampal, dan RTRW Kota Balikpapan.

2. Dinas Pekerjaan Umum (DPU) Kota Balikpapan yang berupa peta rencana lokasi bangunan pengendali banjir DAS Ampal.

\subsection{Analisa Hidrologi}

Analisa hidrologi terdiri dari analisa curah hujan dan analisa debit banjir. Pada tahap analisa hujan rencana, dilakukan analisa perhitungan curah hujan maksimum tahunan untuk mendapatkan besarnya curah hujan periode ulang tertentu di lokasi studi. Hasil perhitungan curah hujan periode ulang kemudian digunakan sebagai tahapan awal untuk memperoleh besarnya debit debit yang melimpas pada DAS 
Ampal. Dalam studi ini, analisa hidrologi dilakukan dengan dua tahapan, yaitu analisa hidrologi saat bangunan pengendali banjir belum terbangun dan analisa hidrologi saat bangunan pengendali banjir telah terbangun.

\subsection{Perbandingan Debit Banjir}

Setelah dilakukan dua tahapan analisa hidrologi, kemudian dilakukan perbandingan debit banjir pada kondisi sekarang dan rencana. Tujuan dari langkah ini adalah untuk mengetahui besarnya debit banjir sebelum dan setelah adanya bangunan pengendali banjir.

\subsection{Analisa Hasil dan Pembahasan}

Hasil penelitian diperoleh dari berbagai langkah yang terdiri dari: identifikasi masalah, pengumpulan data dan analisa data. Hasil analisa berupa besarnya debit banjir yang melimpas di DAS Ampal sebelum dan setelah adanya bangunan pengendali banjir. Hasil ini kemudian menjadi acuan terkait fungsi dan efektifitas bangunan pengendali banjir yang direncanakan di DAS Ampal Kota Balikpapan.

\subsection{Kesimpulan}

Dalam penelitian ini, kesimpulan merupakan pemaparan singkat terkait hasil analisa fungsi dan pengaruh bangunan pengendali banjir DAS Ampal Kota Balikpapan. Langkah-langkah penelitian digambarkan secara singkat melalui diagram alir (Gambar 1) sebagai berikut:

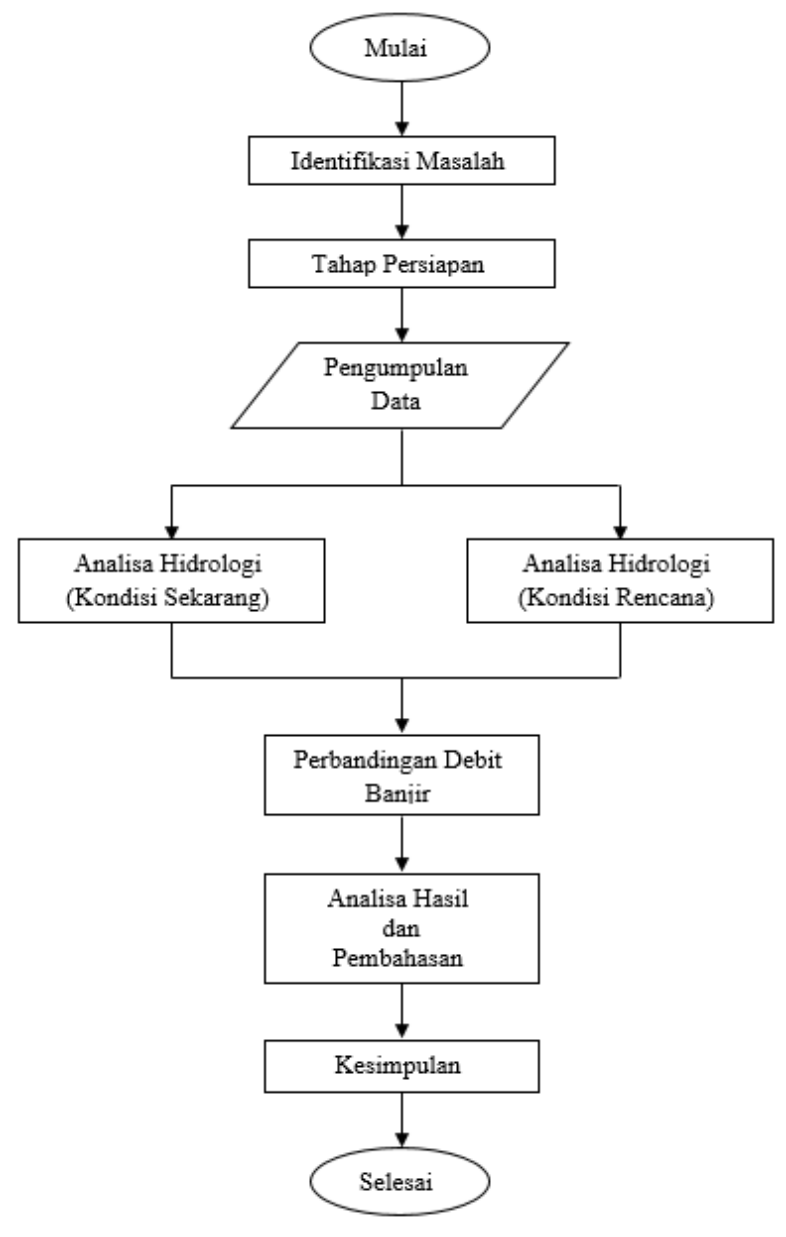

Gambar 1: Diagram Alir Penelitian

Sumber: Penulis, 2017. 


\section{Hasil dan Pembahasan}

\subsection{Lokasi Penelitian}

DAS Ampal atau juga disebut sebagai DAS Klandasan Besar terletak di wilayah administratif Kecamatan Balikpapan Selatan. DAS ini memiliki luas daerah tangkapan sebesar 2527 ha dan sungai utama yaitu sungai Ampal sepanjang 4,699 km (gambar 2). [1] DAS Ampal terdiri dari 22 sub DAS dengan sungai Ampal sebagai muaranya (gambar 3).

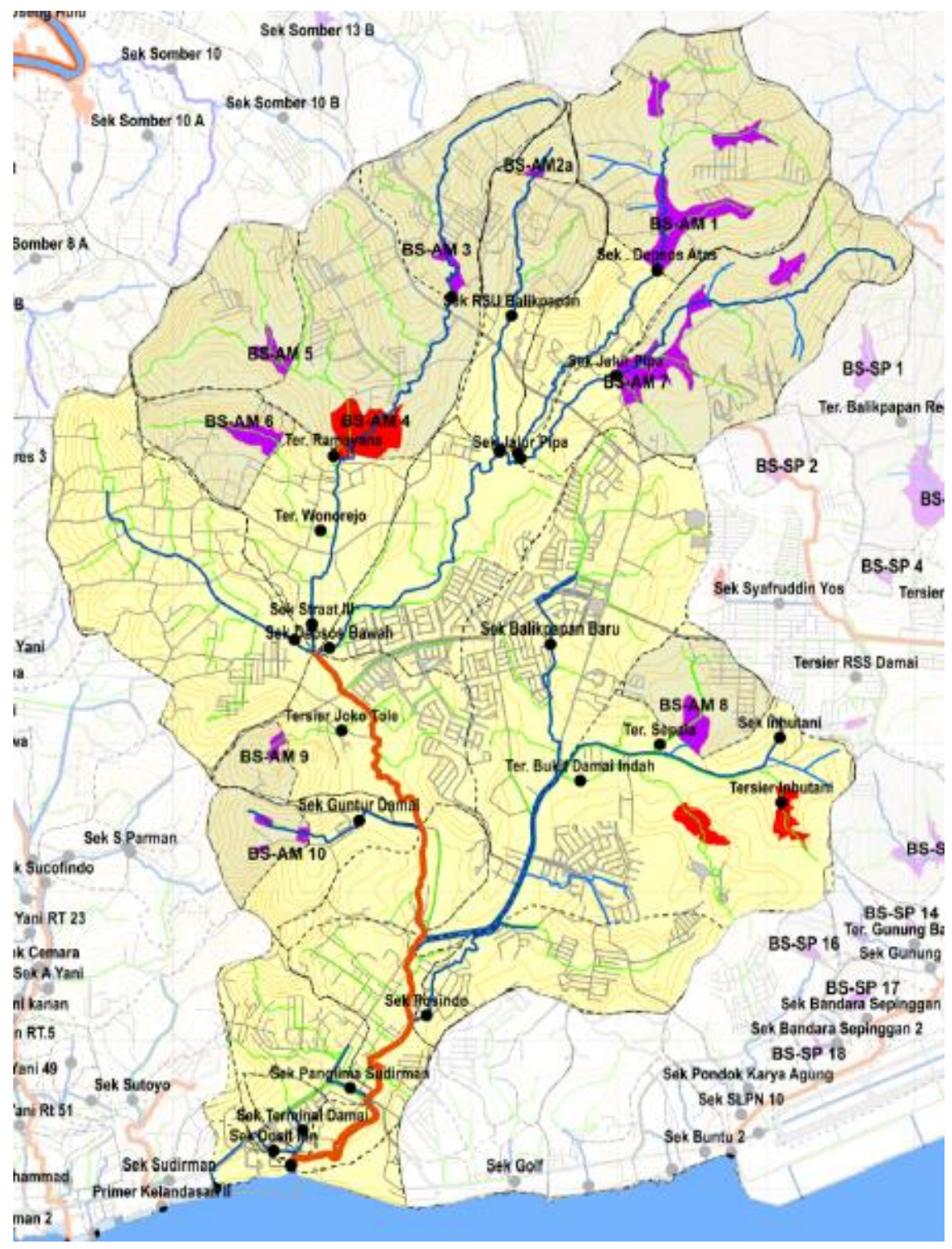

Gambar 2: Daerah Aliran Sungai (DAS) Ampal Sumber: Master Plan Drainase, 2006. 


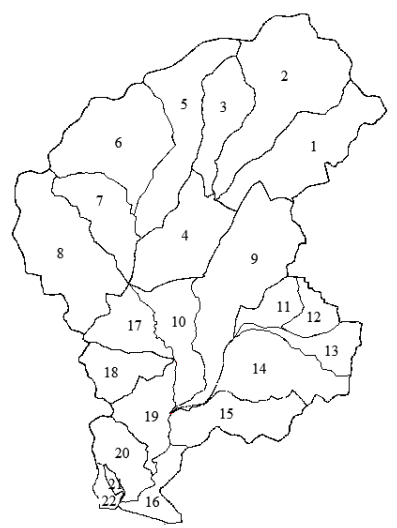

\section{Gambar 3: Lokasi Sub DAS Ampal}

Sumber: Penulis, 2017.

\subsection{Identifikasi Permasalahan}

Sungai Ampal memiliki alur sungai asli yang langsung bermuara ke Selat Makassar, dengan kemiringan dasar sungai yang relatif besar terutama pada daerah hulu. Sungai Ampal yang berada di tengah kota merupakan Saluran Drainase Basin yang membawa banjir dari daerah hulu yang dilewatkan pada daerah perkotaan menuju badan air. Pada musim penghujan, debit banjir yang dikirim dari hulu cukup besar dan sering melampaui kemampuan saluran, sehingga meluap ke lahan dikiri kanan saluran.

Untuk mengatasi permasalahan yang ada pada DAS Ampal, pemerintah Kota Balikpapan melaksanakan program pengendalian banjir berupa pembangunan 3 bangunan pengendali banjir (bendali) dari total 13 bangunan yang telah direncanakan. Pembangunan 3 bendali ini belum mampu mengatasi permasalahan banjir yang terjadi di DAS Ampal. Oleh karena itu, penelitian ini bertujuan untuk menganalisa fungsi serta pengaruh pembangunan 13 bendali di DAS Ampal dalam upaya mengatasi permasalahan banjir yang terjadi.

\subsection{Analisa Hidrologi}

Analisa hidrologi DAS Ampal dilakukan dengan dengan menggunakan data hujan maksimum tahunan Kota Balikpapan selama 13 tahun terhitung mulai tahun 2001 sampai dengan 2013. Dari hasil analisa hidrologi akan diperoleh besarnya debit banjir maksimum yang membebani sungai Ampal sebagai sungai utama DAS Ampal.

\subsubsection{Distribusi Curah Hujan Wilayah}

Analisa curah hujan rencana dilakukan berdasarkan ketersediaan data hujan pada stasiun hujan Sepinggan. Dalam analisa ini digunakan 13 data hujan maksimum sesuai pada tabel 1.

Tabel 1: Data Curah Hujan Maksimum Kota Balikpapan

\begin{tabular}{|c|c|r|}
\hline \multirow{2}{*}{ No. } & \multirow{2}{*}{ Tahun } & Rmax/thn \\
\cline { 3 - 3 } & & $(\mathrm{mm})$ \\
\hline \hline 1 & 2001 & 76.8 \\
\hline 2 & 2002 & 223.0 \\
\hline 3 & 2003 & 181.6 \\
\hline 4 & 2004 & 100.4 \\
\hline 5 & 2005 & 107.5 \\
\hline 6 & 2006 & 133.4 \\
\hline 7 & 2007 & 154.2 \\
\hline
\end{tabular}




\begin{tabular}{|c|c|r|}
\hline \multirow{2}{*}{ No. } & \multirow{2}{*}{ Tahun } & Rmax/thn \\
\cline { 3 - 3 } & & $(\mathrm{mm})$ \\
\hline \hline 8 & 2008 & 164.8 \\
\hline 9 & 2009 & 132.0 \\
\hline 10 & 2010 & 119.7 \\
\hline 11 & 2011 & 119.6 \\
\hline 12 & 2012 & 148.0 \\
\hline 13 & 2013 & 94.0 \\
\hline
\end{tabular}

Sumber: Bappeda Kota Balikpapan, 2014.

\subsubsection{Analisa Curah Hujan Periode Ulang}

Dalam penelitian ini, analisa curah hujan periode ulang menggunakan persamaan distribusi Gumbel Tipe I (Soewarno, 1995). Perhitungan curah hujan menggunakan persamaan distribusi Gumbel Tipe I sebagai berikut:

$$
\mathrm{X}=\bar{X}+(\mathrm{k} \cdot \mathrm{S})
$$

Dimana :

$\mathrm{X}=$ perkiraan nilai yang diharapkan terjadi pada periode ulang tertentu

$\bar{X}=$ nilai rata-rata kejadian

$\mathrm{S}=$ standar deviasi kejadian

$\mathrm{k}$ = faktor frekuensi $\mathrm{k}$ untuk harga ekstrim Gumbel.

Dari perhitungan, diperoleh nilai :

$\bar{X}=135.00$ dan $\mathrm{S}=39.63$

Perhitungan curah hujan periode ulang dituliskan pada tabel 2 sebagai berikut.

Tabel 2: Curah Hujan Periode Ulang Distribusi Gumber Tipe I

\begin{tabular}{|r|r|r|c|}
\hline \multicolumn{1}{|c|}{ Periode Ulang } & Nilai Varian Koreksi & Faktor Frekuensi & Xmax \\
\hline (Tahun) & $(\mathrm{Yt})$ & $(\mathrm{K})$ & $(\mathrm{mm})$ \\
\hline \hline 2 & 0.37 & -0.14 & 129.42 \\
\hline 5 & 1.50 & 1.00 & 174.46 \\
\hline 10 & 2.25 & 1.75 & 204.29 \\
\hline 50 & 3.20 & 2.70 & 241.97 \\
\hline 100 & 3.90 & 3.40 & 269.93 \\
\hline 4.60 & 4.11 & 297.68 \\
\hline
\end{tabular}

Sumber: Penulis, 2017.

Dalam penelitian ini digunakan hujan dengan periode ulang 10 tahun sebagai dasar analisa terkait pengendalian banjir pada DAS Ampal.

\subsubsection{Analisa Debit Banjir DAS Ampal (kondisi sekarang)}

Analisa debit banjir DAS Ampal pada kondisi sekarang dilakukan dengan cara menghitung besarnya debit banjir setelah terbangunnya tiga bangunan pengendali banjir (bendali) yaitu bendali 11, 12, dan 13 yang ditunjukkan dengan simbol segitiga berwarna merah pada gambar 4 . Hal ini bertujuan untuk memperoleh besarnya debit banjir maksimum yang mengalir pada sungai Ampal pada kondisi sekarang (sekarang). Analisa debit banjir DAS Ampal dilakukan dengan menggunakan HEC-HMS. HEC HMS adalah salah satu perangkat lunak yang dikembangkan oleh $U$. S. Army Corps of Engineering. Perangkat 
lunak ini digunakan untuk analisa hidrologi dengan mensimulasikan proses curah hujan dan limpasan langsung (run off) dari sebuah daerah aliran sungai (DAS) (HEC, 2002). Dalam pemodelan HEC-HMS dilakukan dengan input data hujan jam-jaman sesuai dengan perencanaan bangunan pelimpah pada bendali, yaitu periode ulang 10 tahunan. Parameter yang digunakan untuk pemodelan HEC-HMS disesuaikan dengan kondisi di lapangan, parameter yang digunakan antara lain hujan komulatif, tata guna lahan, jenis tanah serta kelembaban.

Hasil analisa debit banjir DAS Ampal kondisi sekarang diperoleh besarnya debit pada tiap-tiap sub DAS dan sungai (tabel 3).

Tabel 3: Debit Banjir DAS Ampal Pada Kondisi Sekarang

\begin{tabular}{|c|c|c|c|}
\hline \multirow{2}{*}{ Nama } & Area & Q & Volume \\
\hline & $\mathrm{km}^{2}$ & $\mathrm{~m}^{3} / \mathrm{det}$ & $1000 \mathrm{~m}^{3}$ \\
\hline Sub DAS 1 & 1.95 & 22.10 & 353.90 \\
\hline Sub DAS 2 & 2.76 & 30.60 & 490.30 \\
\hline Sub DAS 3 & 1.59 & 21.40 & 286.30 \\
\hline Sub DAS 4 & 1.02 & 10.90 & 180.80 \\
\hline Sub DAS 5 & 1.81 & 31.00 & 334.90 \\
\hline Sub DAS 6 & 2.14 & 24.90 & 390.90 \\
\hline Sub DAS 7 & 1.11 & 11.00 & 199.70 \\
\hline Sub DAS 8 & 2.38 & 11.60 & 367.70 \\
\hline Sub DAS 9 & 2.59 & 16.40 & 441.90 \\
\hline Sub DAS 10 & 1.05 & 15.90 & 187.80 \\
\hline Sub DAS 11 & 0.25 & 6.00 & 44.10 \\
\hline Sub DAS 12 & 0.32 & 6.00 & 56.60 \\
\hline Sub DAS 13 & 0.43 & 7.10 & 80.80 \\
\hline Sub DAS 14 & 0.98 & 11.70 & 181.10 \\
\hline Sub DAS 17 & 0.82 & 10.30 & 142.40 \\
\hline Sub DAS 18 & 0.76 & 12.90 & 131.40 \\
\hline Sub DAS 19 & 0.88 & 14.80 & 152.10 \\
\hline Sub DAS 20 & 0.60 & 11.60 & 108.00 \\
\hline Sub DAS 21 & 0.06 & 1.60 & 10.80 \\
\hline Sub DAS 22 & 0.16 & 2.50 & 27.20 \\
\hline Sungai 1 & 1.95 & 22.10 & 353.50 \\
\hline Sungai 2 & 2.76 & 30.60 & 489.70 \\
\hline Sungai 3 & 1.59 & 21.40 & 286.10 \\
\hline Sungai 4.1 & 1.02 & 10.90 & 180.80 \\
\hline Sungai 4.2 & 5.73 & 63.50 & 1023.60 \\
\hline Sungai 4.3 & 7.32 & 82.10 & 1309.30 \\
\hline Sungai 5.1 & 1.81 & 31.00 & 334.30 \\
\hline Sungai 5.2 & 3.95 & 9.80 & 405.30 \\
\hline Sungai 5.3 & 5.06 & 18.50 & 601.30 \\
\hline Sungai 6 & 2.14 & 24.90 & 390.60 \\
\hline Sungai 7 & 1.11 & 11.00 & 199.50 \\
\hline Sungai 8 & 2.38 & 11.60 & 362.70 \\
\hline
\end{tabular}


Analisa Fungsi dan Pengaruh Bangunan Pengendali Banjir DAS Ampal Kota Balikpapan

\begin{tabular}{|c|c|c|c|}
\hline \multirow{2}{*}{ Nama } & Area & $\mathrm{Q}$ & Volume \\
\hline & $\mathrm{km}^{2}$ & $\mathrm{~m}^{3} / \mathrm{det}$ & $1000 \mathrm{~m}^{3}$ \\
\hline Sungai 9 & 2.59 & 16.40 & 437.30 \\
\hline Sungai 10 & 1.05 & 15.90 & 187.80 \\
\hline Sungai 11 & 0.25 & 6.00 & 44.00 \\
\hline Sungai 12 & 0.32 & 6.00 & 56.60 \\
\hline Sungai 13.1 & 0.43 & 7.10 & 80.80 \\
\hline Sungai 13.2 & 0.43 & 2.40 & 75.00 \\
\hline Sungai 14.1 & 0.98 & 11.70 & 181.10 \\
\hline Sungai 14.2 & 0.98 & 4.90 & 163.90 \\
\hline Sungai 15 & 1.12 & 17.20 & 196.30 \\
\hline Sungai 16 & 0.48 & 10.80 & 86.70 \\
\hline Sungai 17 & 0.82 & 10.30 & 142.40 \\
\hline Sungai 18 & 0.76 & 12.90 & 131.30 \\
\hline Sungai 19 & 0.88 & 14.80 & 152.00 \\
\hline Sungai 20 & 0.60 & 11.60 & 108.00 \\
\hline Sungai 21 & 0.06 & 1.60 & 10.80 \\
\hline Sungai 22 & 0.16 & 2.50 & 27.10 \\
\hline Sungai 23.1 & 0.43 & 2.40 & 74.40 \\
\hline Sungai 23.2 & 1.00 & 10.60 & 174.70 \\
\hline Sungai 23.3 & 1.98 & 11.00 & 336.50 \\
\hline Ampal 1 & 14.76 & 100.20 & 2267.40 \\
\hline Ampal 2 & 15.58 & 109.00 & 2400.30 \\
\hline Ampal 3 & 16.34 & 115.30 & 2527.80 \\
\hline Ampal 4 & 17.39 & 125.90 & 2715.20 \\
\hline Ampal 5 & 19.98 & 131.50 & 3151.60 \\
\hline Ampal 6 & 21.96 & 141.00 & 3485.80 \\
\hline Ampal 7 & 22.84 & 148.30 & 3636.80 \\
\hline Ampal 8 & 23.96 & 159.80 & 3831.10 \\
\hline Ampal 9 & 24.44 & 163.20 & 3914.20 \\
\hline Ampal 10 & 25.04 & 168.50 & 4015.30 \\
\hline $\mathrm{A}$ & 5.06 & 18.50 & 604.80 \\
\hline $\mathrm{B}$ & 5.73 & 63.50 & 1024.00 \\
\hline $\mathrm{C}$ & 7.32 & 82.10 & 1309.70 \\
\hline $\mathrm{D}$ & 1.00 & 10.60 & 175.10 \\
\hline $\mathrm{E}$ & 1.98 & 11.00 & 338.50 \\
\hline $\mathrm{F}$ & 0.43 & 2.40 & 75.00 \\
\hline 1 & 14.76 & 100.20 & 2273.30 \\
\hline 2 & 15.58 & 109.00 & 2409.80 \\
\hline 3 & 16.34 & 115.30 & 2531.60 \\
\hline 4 & 17.39 & 125.90 & 2715.60 \\
\hline 5 & 19.98 & 131.50 & 3152.50 \\
\hline 6 & 21.96 & 141.00 & 3488.00 \\
\hline
\end{tabular}




\begin{tabular}{|c|r|r|r|}
\hline \multirow{2}{*}{ Nama } & Area & Q & \multicolumn{1}{|c|}{ Volume } \\
\cline { 2 - 4 } & $\mathrm{km}^{2}$ & $\mathrm{~m}^{3} / \mathrm{det}$ & $1000 \mathrm{~m}^{3}$ \\
\hline \hline 7 & 22.84 & 148.30 & 3637.80 \\
\hline 8 & 23.96 & 159.80 & 3833.10 \\
\hline 9 & 24.44 & 163.20 & 3917.80 \\
\hline 10 & 25.04 & 168.50 & 4022.20 \\
\hline 11 & 25.26 & 170.40 & 4053.20 \\
\hline Reservoir 11 & 0.98 & 4.90 & 164.30 \\
\hline Reservoir 12 & 0.43 & 2.40 & 75.10 \\
\hline Reservoir 13 & 3.95 & 9.80 & 408.10 \\
\hline \multicolumn{5}{|c|}{ Sumber: Penulis, 2017.} \\
\hline
\end{tabular}

Tabel 3 menunjukkan hasil analisa rencana DAS Ampal dengan tidak memperhitungkan nilai baseflow. Dari hasil analisa, diketahui bahwa debit maksimum yang terjadi sungai ampal bagian hilir (junction 11) adalah sebesar $170.40 \mathrm{~m}^{3} /$ det. Nilai debit banjir ini diperoleh dari perhitungan total limpasan hujan permukaan pada 10 sub DAS yang bermuara di sungai Ampal.

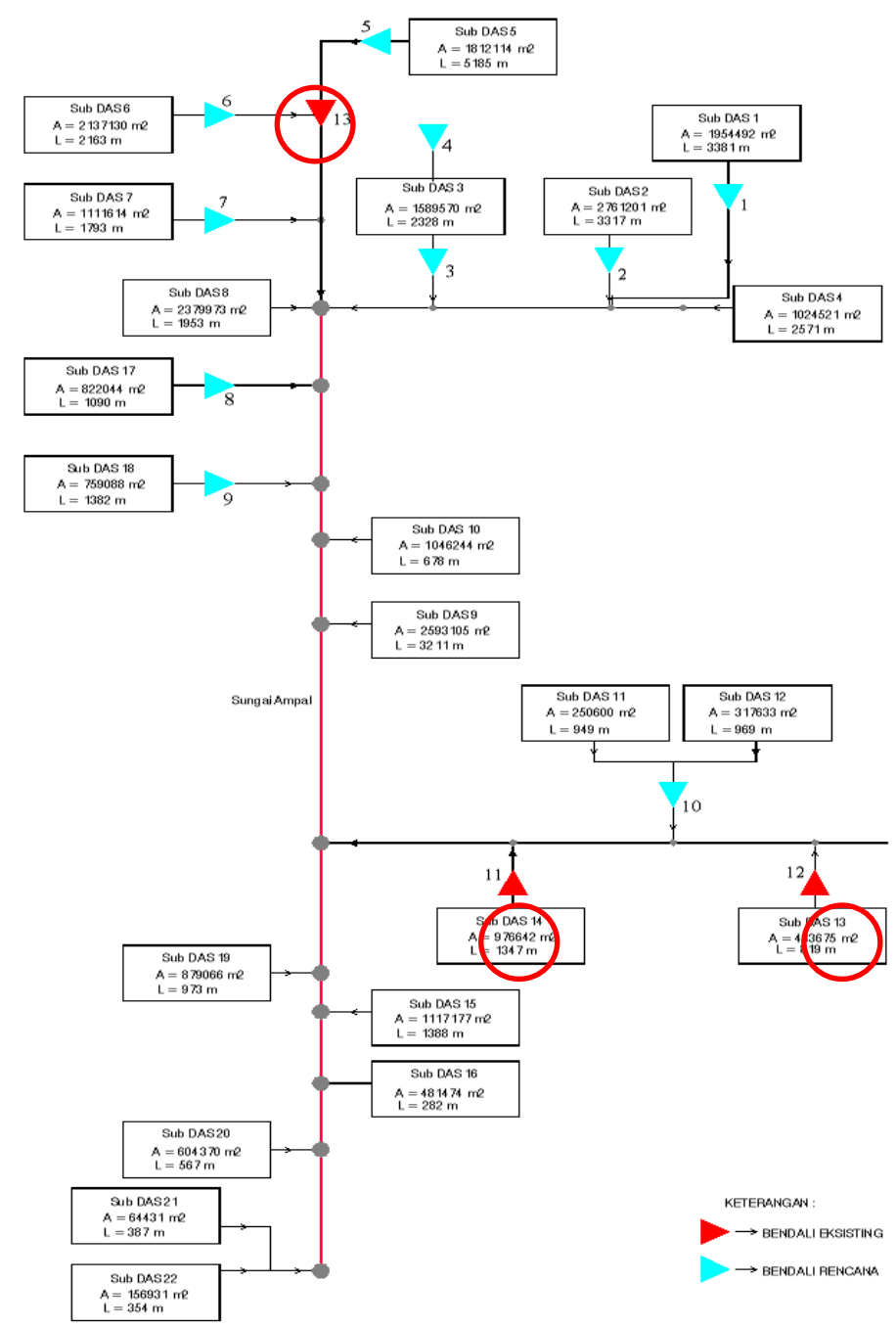

Gambar 4: Peta Skematik DAS Ampal

Sumber: Penulis, 2017 


\subsubsection{Analisa Debit Banjir DAS Ampal (kondisi rencana)}

DAS Ampal direncanakan memiliki 13 bangunan pengendali banjir (bendali) terbangun yang bertujuan untuk mengurangi volume genangan (gambar 4). Sampai pada tahun 2017, hanya terbangun tiga bendali yaitu bendali 11, 12, dan 13. Analisa ini dilakukan dengan tujuan untuk mengetahui besarnya debit puncak banjir yang mengalir pada sungai Ampal setelah semua bendali terbangun. Sama halnya dengan analisa kondisi eksisting, pada kondisi rencana analisa debit banjir DAS Ampal juga dilakukan dengan menggunakan HEC-HMS. Dalam pemodelan HEC-HMS dilakukan dengan input data hujan jam-jaman sesuai dengan perencanaan bangunan pelimpah pada bendali, yaitu periode ulang 10 tahunan. Parameter yang digunakan untuk pemodelan HEC-HMS adalah perhitungan yang disesuaikan dengan kondisi di lapangan.

Hasil analisa debit banjir DAS Ampal kondisi eksisting diperoleh besarnya debit pada tiap-tiap sub DAS dan sungai (tabel 4).

Tabel 4: Debit Banjir DAS Ampal Pada Kondisi Rencana

\begin{tabular}{|c|c|c|c|}
\hline \multirow{2}{*}{ Nama } & Area & Q & Volume \\
\hline & $\mathrm{km} 2$ & $\mathrm{~m} 3 /$ det & $1000 \mathrm{~m} 3$ \\
\hline Sub DAS 1 & 1.95 & 22.10 & 353.90 \\
\hline Sub DAS 2 & 2.76 & 30.60 & 490.30 \\
\hline Sub DAS 3 & 1.59 & 21.40 & 286.30 \\
\hline Sub DAS 4 & 1.02 & 10.90 & 180.80 \\
\hline Sub DAS 5 & 1.81 & 31.00 & 334.90 \\
\hline Sub DAS 6 & 2.14 & 24.90 & 390.90 \\
\hline Sub DAS 7 & 1.11 & 11.00 & 199.70 \\
\hline Sub DAS 8 & 2.38 & 11.60 & 419.00 \\
\hline Sub DAS 9 & 2.59 & 16.40 & 457.50 \\
\hline Sub DAS 10 & 1.05 & 15.90 & 187.80 \\
\hline Sub DAS 11 & 0.25 & 6.00 & 44.10 \\
\hline Sub DAS 12 & 0.32 & 5.60 & 56.60 \\
\hline Sub DAS 13 & 0.43 & 7.10 & 80.80 \\
\hline Sub DAS 14 & 0.98 & 11.70 & 181.10 \\
\hline Sub DAS 15 & 1.12 & 17.20 & 196.40 \\
\hline Sub DAS 16 & 0.48 & 10.80 & 86.70 \\
\hline Sub DAS 17 & 0.82 & 10.30 & 142.40 \\
\hline Sub DAS 18 & 0.76 & 12.90 & 131.40 \\
\hline Sub DAS 19 & 0.88 & 14.80 & 152.10 \\
\hline Sub DAS 20 & 0.60 & 11.60 & 108.00 \\
\hline Sub DAS 21 & 0.06 & 1.60 & 10.80 \\
\hline Sub DAS 22 & 0.16 & 2.50 & 27.20 \\
\hline Sungai 1.1 & 1.95 & 22.10 & 353.70 \\
\hline Sungai 1.2 & 1.95 & 4.60 & 323.00 \\
\hline Sungai 2.1 & 2.76 & 30.60 & 490.10 \\
\hline Sungai 2.2 & 2.76 & 5.00 & 398.60 \\
\hline Sungai 3.1 & 1.59 & 21.40 & 286.30 \\
\hline
\end{tabular}


Analisa Fungsi dan Pengaruh Bangunan Pengendali Banjir DAS Ampal Kota Balikpapan

\begin{tabular}{|c|c|c|c|}
\hline \multirow{2}{*}{ Nama } & Area & Q & Volume \\
\hline & $\mathrm{km} 2$ & $\mathrm{~m} 3 / \mathrm{det}$ & $1000 \mathrm{~m} 3$ \\
\hline Sungai 3.2 & 1.59 & 12.30 & 286.30 \\
\hline Sungai 3.3 & 1.59 & 5.50 & 285.10 \\
\hline Sungai 4.1 & 1.02 & 10.90 & 180.80 \\
\hline Sungai 4.2 & 5.73 & 15.70 & 900.70 \\
\hline Sungai 4.3 & 7.32 & 19.20 & 1184.10 \\
\hline Sungai 5.1 & 1.81 & 31.00 & 334.50 \\
\hline Sungai 5.2 & 1.81 & 9.40 & 334.40 \\
\hline Sungai 5.3 & 3.95 & 7.60 & 658.70 \\
\hline Sungai 5.4 & 5.06 & 8.70 & 788.80 \\
\hline Sungai 6.1 & 2.14 & 24.90 & 390.70 \\
\hline Sungai 6.2 & 2.14 & 9.40 & 390.50 \\
\hline Sungai 7.1 & 1.11 & 11.00 & 199.70 \\
\hline Sungai 7.2 & 1.11 & 1.10 & 132.10 \\
\hline Sungai 8 & 2.38 & 11.60 & 418.90 \\
\hline Sungai 9 & 2.59 & 16.40 & 457.30 \\
\hline Sungai 10 & 1.05 & 15.90 & 187.80 \\
\hline Sungai 11.1 & 0.25 & 6.00 & 44.00 \\
\hline Sungai 11.2 & 0.57 & 2.10 & 99.50 \\
\hline Sungai 12 & 0.32 & 2.10 & 56.60 \\
\hline Sungai 13.1 & 0.43 & 7.10 & 80.80 \\
\hline Sungai 13.2 & 0.43 & 2.40 & 80.80 \\
\hline Sungai 14.1 & 0.98 & 11.70 & 181.10 \\
\hline Sungai 14.2 & 0.98 & 4.90 & 181.10 \\
\hline Sungai 15 & 1.12 & 17.20 & 196.30 \\
\hline Sungai 16 & 0.48 & 10.80 & 86.70 \\
\hline Sungai 17.1 & 0.82 & 10.30 & 142.40 \\
\hline Sungai 17.2 & 0.82 & 5.50 & 142.40 \\
\hline Sungai 18.1 & 0.76 & 12.90 & 131.40 \\
\hline Sungai 18.2 & 0.76 & 5.80 & 131.40 \\
\hline Sungai 19 & 0.88 & 14.80 & 152.00 \\
\hline Sungai 20 & 0.60 & 11.60 & 108.00 \\
\hline Sungai 21 & 0.06 & 1.60 & 10.80 \\
\hline Sungai 22 & 0.16 & 2.50 & 27.10 \\
\hline Sungai 23.1 & 0.43 & 2.40 & 80.70 \\
\hline Sungai 23.2 & 1.00 & 4.60 & 180.10 \\
\hline Sungai 23.3 & 1.98 & 9.40 & 360.90 \\
\hline Ampal 1 & 14.76 & 35.80 & 2388.40 \\
\hline Ampal 2 & 15.58 & 39.70 & 2525.10 \\
\hline Ampal 3 & 16.34 & 43.20 & 2654.20 \\
\hline Ampal 4 & 17.39 & 46.20 & 2841.80 \\
\hline Ampal 5 & 19.98 & 62.20 & 3298.60 \\
\hline Ampal 6 & 21.96 & 71.50 & 3658.40 \\
\hline
\end{tabular}




\begin{tabular}{|c|c|c|c|}
\hline \multirow{2}{*}{ Nama } & Area & Q & Volume \\
\hline & $\mathrm{km} 2$ & $\mathrm{~m} 3 /$ det & $1000 \mathrm{~m} 3$ \\
\hline Ampal 7 & 22.84 & 74.10 & 3809.90 \\
\hline Ampal 8 & 23.96 & 79.00 & 4005.20 \\
\hline Ampal 9 & 24.44 & 80.40 & 4090.00 \\
\hline Ampal 10 & 25.04 & 82.90 & 4194.40 \\
\hline $\mathrm{A}$ & 5.06 & 8.70 & 790.80 \\
\hline $\mathrm{B}$ & 5.73 & 15.70 & 902.40 \\
\hline $\mathrm{C}$ & 7.32 & 19.20 & 1185.80 \\
\hline $\mathrm{D}$ & 1.00 & 4.60 & 180.20 \\
\hline $\mathrm{E}$ & 1.98 & 9.40 & 361.20 \\
\hline $\mathrm{F}$ & 0.43 & 2.40 & 80.80 \\
\hline 1 & 14.76 & 35.80 & 2391.80 \\
\hline 2 & 15.58 & 39.70 & 2530.80 \\
\hline 3 & 16.34 & 43.20 & 2656.50 \\
\hline 4 & 17.39 & 46.20 & 2842.00 \\
\hline 5 & 19.98 & 62.20 & 3299.20 \\
\hline 6 & 21.96 & 71.50 & 3659.50 \\
\hline 7 & 22.84 & 74.10 & 3810.40 \\
\hline 8 & 23.96 & 79.00 & 4006.20 \\
\hline 9 & 24.44 & 80.40 & 4091.80 \\
\hline 10 & 25.04 & 8290 & 4198.00 \\
\hline 11 & 25.26 & 83.80 & 4232.30 \\
\hline Reservoir 1 & 1.95 & 4.60 & 323.70 \\
\hline Reservoir 2 & 2.76 & 5.00 & 400.10 \\
\hline Reservoir 3 & 1.59 & 5.50 & 285.30 \\
\hline Reservoir 4 & 1.59 & 12.30 & 286.30 \\
\hline Reservoir 5 & 1.81 & 9.40 & 334.50 \\
\hline Reservoir 6 & 2.14 & 9.40 & 390.60 \\
\hline Reservoir 7 & 1.11 & 1.10 & 132.70 \\
\hline Reservoir 8 & 0.82 & 5.50 & 142.40 \\
\hline Reservoir 9 & 0.76 & 5.80 & 131.40 \\
\hline Reservoir 10 & 0.57 & 2.10 & 99.50 \\
\hline Reservoir 11 & 0.98 & 4.90 & 181.10 \\
\hline Reservoir 12 & 0.43 & 2.40 & 80.80 \\
\hline Reservoir 13 & 3.95 & 7.60 & 659.90 \\
\hline
\end{tabular}

Dari tabel 4 menunjukkan hasil analisa kondisi rencana DAS Ampal dengan tidak memperhitungkan nilai baseflow. Dari hasil analisa, diketahui bahwa debit maksimum yang terjadi sungai ampal bagian hilir (junction 11) adalah sebesar $83.80 \mathrm{~m}^{3} /$ det. Nilai debit ini relatif lebih rendah dibandingkan dengan kondisi sekarang karena pada kondisi rencana debit banjir ditampung menggunakan 13 bangunan pengendali banjir (bendali) yang diletakkan di anak sungai Ampal. 


\subsubsection{Perbandingan Debit Banjir}

Berdasarkan hasil analisa kondisi sekarang dan eksisting diperoleh nilai debit banjir sebesar 170.40 $\mathrm{m} 3 /$ det dan $83.80 \mathrm{~m} 3 /$ det. Kondisi ini dipengaruhi oleh jumlah bangunan pengendali banjir yang terbangun pada anak sungai Ampal. Dengan adanya penambahan 10 bangunan pengendali banjir, maka nilai debit banjir mengalami penurunan sebesar $86.60 \mathrm{~m} 3 /$ det.

\section{Kesimpulan}

Berdasarkan hasil analisa pada poin sebelumnya, diperoleh hasil sebagai berikut :

1. Pada kondisi eksisting (terbangun 3 bangunan pengendali banjir), besarnya debit puncak banjir yang mengalir pada sungai Ampal adalah sebesar 170,40 m³/det.

2. Pada kondisi rencana (terbangun 13 bangunan pengendali banjir), besarnya debit puncak banjir yang mengalir pada sungai Ampal adalah sebesar $83,80 \mathrm{~m}^{3} / \mathrm{det}$.

3. Besarnya penurunan debit banjir dari kondisi eksisting ke kondisi rencana adalah sebesar 86,60 $\mathrm{m}^{3} / \mathrm{det}$.

\section{Daftar Pustaka}

Bappeda Kota Balikpapan, 2006, 'Appendix Hidrologi Kota Balikpapan'.

FTSP ITS, 2006, 'Appendix Deskripsi Sungai'.

FTSP ITS, 2006, 'Master Plan Drainase Kota Balikpapan'.

Hydrologic Engineering Centre, 2002, 'HEC-HMS Hydrolic Modelling System (Hydraulic Reference Manual)', US Army Corps of Engineering, Davis, CA.

Soewarno, 1995, Hidrologi “Aplikasi Metode Statistik untuk Analisa Data”, Nova, Bandung. 
Analisa Fungsi dan Pengaruh Bangunan Pengendali Banjir DAS Ampal Kota Balikpapan

Halaman ini sengaja dikosongkan 